\title{
Chemical Management of Phytophthora capsicin Pumpkin in Illinois
}

\author{
Mohammad Babadoost ${ }^{1 *}$ and Jose R de Souza ${ }^{2}$ \\ Department of Sciences, University of Illinois, Brazil \\ *Corresponding author: Mohammad Babadoost, Department of Sciences, University of Illinois, Urbana, USA
}

Submission: 漈 September 28, 2017; Published: 眥 April 02, 2018

\begin{abstract}
Phytophthora blight, caused by Phytophthora capsici, is a destructive disease of cucurbits and peppers in Illinois and worldwide. Fungicide use is a significant component of management strategies of $P$. capsici in cucurbits and peppers in the United States. Studies were conducted in the laboratory and field to evaluate efficacy of selected fungicides for control of $P$. capsici in pumpkin in Illinois. In the laboratory, sensitivity of five $P$. capsici isolates from Illinois was evaluated to the fungicides cyazofamid, dimethomorph, and mandipropamid. Development of colonies and production of sporangia of the isolates were assessed at concentrations of $0.0,0.1,0.5,1.0,5.0$, and $10.0 \mu \mathrm{g} / \mathrm{mL}$ of cyazofamid, $0.0,0.1,0.5,1.0,2.5$, and $5.0 \mu \mathrm{g} / \mathrm{mL}$ of dimethomorph; and $0.0,0.05,0.1,0.5,1.0$, and $5.0 \mu \mathrm{g} / \mathrm{mL}$ of mandipropamid in V8 juice agar in Petri plates. In 2014, 2015, and 2017, effectiveness of the fungicides cyazofamid, dimethomorph, and mandipropamid for control of $P$. capsici in pumpkin was investigated.

In 2014, incidence of fruit rot caused by P. capsici was $31 \%$ in control plots and 5, 10, and $2 \%$ in the plots treated with cyazofamid, dimethomorph, and mandipropamid, respectively. In 2015, incidence of fruit rot caused by P. capsici was $69 \%$ in control plots and 42, 21, and 26\% in the plots sprayed with cyazofamid, dimethomorph, and mandipropamid, respectively. Similarly in 2017, incidence of fruit rot caused by P. capsici was $48 \%$ in control plots and 7,27 , and $13 \%$ in the plots sprayed with cyazofamid, dimethomorph, and mandipropamid, respectively. In all field trials, percent vines infected with P. capsiciin treated plots with cyazofamid, dimethomorph, and mandipropamid was significantly lower than that of control plots.
\end{abstract}

Keywords: Phytophthora capsici; Oomycete; Soilborne pathogen; Fungicide resistance; Fruit rot; Pumpkin; Cucurbit

\section{Introduction}
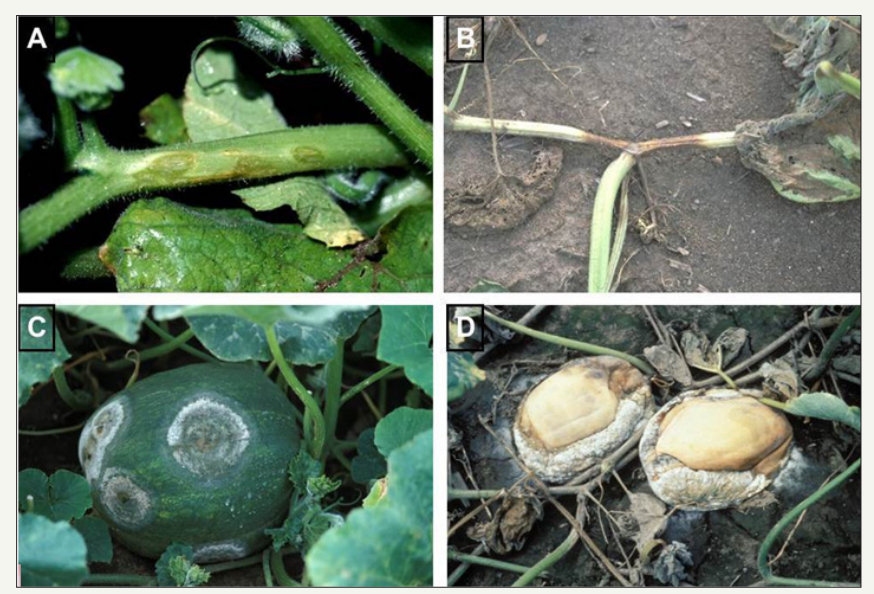

Figure 1: Pumpkin vines and fruit infected by Phytophthora capsici.
A. A newly infected vine
B. An advance infection in a vine
C. A newly infected fruit
D. Advance infection of fruit

Phytophthora blight, caused by the Oomycete Phytophthora capsici, has become one of the most serious threats to cucurbit and pepper production worldwide [1-5]. P. capsici can attack the host plant at any growth stage causing up to $100 \%$ crop loss $[3,6]$. The pathogen causes seedling death, crown rot, foliar blight (Figure $1 \mathrm{~A}$ \&1B) and fruit rot (Figure 1C \& 1D) in cucurbits $[3,7,8]$, and causes root rot, crown rot, foliar blight, and fruit rot in peppers $[4,9,10]$. $P$. capsici can also infect plant species in 15 families [3,11].

Phytophthora capsici is a soil-borne pathogen and produces oospores, sporangia, and zoospores. The pathogen survives between crops as oospores in soil [3,12]. Oospores are resistant to desiccation, cold temperatures, and other extreme environmental conditions, and can survive in the soil, in the absence of a host plant, for several years. Oospores germinate and produce sporangia and zoospores [2,7]. Zoospores are released in water, dispersed by irrigation or surface water, and infect plant tissues. If the environmental conditions are conducive (moist and warm), the disease develops rapidly $[3,5,7,12]$.

The recommended management strategies for $P$. capsici in vegetables include selecting well-drained sites, planting resistant cultivars (for peppers), crop rotation, and application of fungicides $[1,3,5,13]$. Since there is no cucurbit resistant to P. capsici, use of fungicides is essential for controlling this pathogen in cucurbit crops. $P$. capsici is a multi-cycle pathogen and quickly develops resistance to fungicides. Thus, in each area, the efficacy of the fungicides for management of $P$. capsici should be assessed and the 
use of fungicides should be monitored carefully. Over the past 16 years, several fungicides have been developed for management of oomycete pathogens, including Phytophthora spp.

Some of these fungicides are effective against P. capsici. Cyazofamid, dimethomorph, and mandipropamid are commonly used fungicides to manage $P$. capsici in cucurbits in Illinois and other vegetable growing areas. These fungicides have different modes of action and can be used together. This study was conducted to determine the efficacy of these fungicides for managing $P$. capsici in pumpkin production.

\section{Materials and Methods}

\section{Phytophthora capsici isolates}

Five isolates of $P$. capsici were selected from the collection maintained in Dr. Babadoost's laboratory at the University of Illinois for this study. The isolates were grown on V8-juice agar in Petri plates. V-8 juice agar was prepared by adding $50 \mathrm{ml}$ of V8 juice, $1.0 \mathrm{~g}$ of $\mathrm{CaCO}_{3}$, and $16 \mathrm{~g}$ of agar to $950 \mathrm{~mL}$ of distilled water.

\section{Fungicides}

Three fungicides were used in this study, including cyazofamid (FRAC code 21), dimethomorph (FRAC code 40), and mandipropamid (FRAC code 40). Commercial names of the fungicides in the United States (US) are Ranman 400 SC, Forum 4.16 SC, and Revus 2.09 SC for cyazofamid, dimethomorph, and mandipropamid, respectively.

\section{Inhibition of mycelia growth}

An in-vitro mycelial growth assay was conducted to determine the effective fungicide concentration at which $50 \%$ of the fungal growth was inhibited (EC50) for each isolate-fungicide combination. Plugs of $7 \mathrm{~mm}$ diameter from actively growing cultures of $P$. capsici were transferred onto V8 juice agar in Petri plates amended with technical grades of the fungicides: cyazofamid at $0.0,0.1,0.5,1.0$, 5.0 , and $10.0 \mu \mathrm{g} / \mathrm{mL}$; dimethomorph at $0.0,0.1,0.5,1.0,2.5$, and $5.0 \mu \mathrm{g} / \mathrm{mL}$; mandipropamid at $0.0,0.05,0.1,0.5,1.0$, and $5.0 \mu \mathrm{g} / \mathrm{mL}$; and A209410D at $0,1,10,50,100$, and $200 \mu \mathrm{g} / \mathrm{mL}$. For assays, the stock solutions of fungicides were diluted with methanol, acetone, or water. Four plates were used for each fungicide-concentration combination. Culture plates were incubated at $25{ }^{\circ} \mathrm{C}$ in darkness. Two perpendicular diameters of colonies were measured 4 days after incubation. The experiment was repeated once under the same conditions.

\section{Inhibition of sporangium formation}

Phytophthora capsici isolates were grown on V8 juice agar in Petri plates at $25^{\circ} \mathrm{C}$ in the dark for 4 days. Then, plugs of $10 \mathrm{~mm}$ were cut from the edge of the colonies. Three $10 \mathrm{~mm} 2$ plugs were placed with the mycelium side up in a Petri plate containing sterilized distilled water (SDW) amended with fungicides cyazofamid at 0.0 , $0.1,0.5,1.0,5.0$, and $10.0 \mu \mathrm{g} / \mathrm{mL}$; dimethomorph at $0.0,0.1,0.5,1.0$, $2.5,5.0$, and $10.0 \mu \mathrm{g} / \mathrm{mL}$; and mandipropamid at $0.0,0.05,0.1,0.5$, 1.0, 5.0, and $10.0 \mu \mathrm{g} / \mathrm{mL}$. The Petri plates were incubated at $25^{\circ} \mathrm{C}$ under continuous light [13]. After $48 \mathrm{~h}$, agar plugs with the colonies were placed on glass slides, stained and fixed with $0.01 \%(\mathrm{w} / \mathrm{v})$ fuchsin acid in $85 \%$ lactic acid.

The number of sporangia was counted on two of the agar plugs using a light microscope. The fungicide concentration at which $50 \%$ of sporangia production was reduced $\left(\mathrm{EC}_{50}\right)$ was determined. The experiment was repeated once. Percent of suppression of sporangium formation was calculated from the ratio of the number of sporangia produced in the fungicide-amended plates to the number of sporangia in the control plates.

\section{Field trials}

In 2014, 2015 and 2017, trials were conducted in an irrigated field near Green Valley City (Tazewell County), Illinois to evaluate efficacy of selected fungicides for control of Phytophthora blight of pumpkin, caused by P. capsici (Tables 1-3). Seeds were sown on 7 May, 14 May and 15 May in 2014, 2015, and 2017, respectively. Due to continuous heavy rains in 2015 , the plots were lost and the trial was re-established using 2-week old transplants on 1 August 2015. Seeds of the processing pumpkin Cucurbita moschata Duchesne 'Dickinson' were sown $45 \mathrm{~cm}$ apart in single-row plots, $6 \mathrm{~m}$ long. The plots were spaced $9 \mathrm{~m}$ apart in a randomized complete block design with four replications.

Table 1: Occurrence of Phytophthora infection of pumpkin leaves and fruits, caused by Phytophthora capsici, following applications of the fungicides in 2014 in Illinois.

\begin{tabular}{|c|c|c|}
\hline \multirow{2}{*}{ Fungicidez Treatment and Rate/Ha (Application Timing)y } & \multicolumn{2}{|c|}{ Phytophthora Infection } \\
\hline & Infected Vines (\%)x & Infected Fruit(\%)w \\
\hline Untreated check & $38.75 \mathrm{av}$ & $30.68 \mathrm{a}$ \\
\hline Ranman 400F, 200mL + Silwet L-77, 146mL [1-9] & $10.00 \mathrm{c}$ & $9.61 b$ \\
\hline $\begin{array}{c}\text { Ranman 400F, 200mL + Silwet L-77, } 146 \mathrm{~mL}[1,3,5,7,9] \text { alt Revus } 2.09 \mathrm{SC}, 583 \mathrm{~mL}+\text { Activator-90, } \\
0.25 \%[2,4,6,8]\end{array}$ & $6.25 \mathrm{c}$ & $5.72 b$ \\
\hline $\begin{array}{l}\text { Revus 2.09SC, 583mL + Kocide-3000 46.1DF, } 1.683 \mathrm{~kg}+\text { Activator- } 900.125 \%[1,3,5,7,9] \text { alt Ranman } \\
\text { 400F, 200mL + Silwet L-77, } 146 \mathrm{~mL}[2,4,6,8]\end{array}$ & $13.75 \mathrm{c}$ & $4.45 \mathrm{~b}$ \\
\hline $\begin{array}{c}\text { Revus 2.09SC, 583mL + Kocide-3000 46.1DF, } 1.683 \mathrm{~kg}[1,3,5,7,9] \text { alt Forum } 4.16 \mathrm{SC}, 437 \mathrm{~mL}+ \\
\text { Kocide-3000 46.1DF, 1.683kg }[2,4,6,8]\end{array}$ & $10.00 \mathrm{c}$ & $10.14 \mathrm{~b}$ \\
\hline $\begin{array}{c}\text { Revus 2.09SC, } 583 \mathrm{~mL}+\text { Kocide-3000 46.1DF, } 1.683 \mathrm{~kg}+\text { Activator } 90,0.125 \%[1,3,5,7,9] \text { alt Forum } \\
\text { 4.16SC, } 437 \mathrm{~mL}+\text { Kocide-3000 46.1DF, } 1.683 \mathrm{~kg}+\text { Activator- } 90,0.25 \%[2,4,6,8]\end{array}$ & $25.00 \mathrm{~b}$ & $4.89 \mathrm{~b}$ \\
\hline $\operatorname{LSD}(\mathrm{P}=0.05)$ & 10.25 & 9.38 \\
\hline
\end{tabular}


${ }^{2}$ Activator-90 = a nonionic spray adjuvant; Forum 4.16SC = dimethomorph; Kocide-3000 46.1DF = copper hydroxide; Ranman 400F = cyazofamid; Revus 2.09SC = mandipropamid; and Silwet L-77 = a spreader-sticker adjuvant.

${ }^{y}$ Application date: $1=12$ June; $2=19$ June; $3=26$ June; $4=3$ July; $5=10$ July; $6=17$ July; $7=24$ July; $8=31$ July; and 9= 7 August 2014

${ }^{x}$ Vine infection was assessed on 18 August 2014.

wFruit infection was assessed on 29 August 2014 (at harvest).

"Values are averages of four replications. Values within each column with a letter in common are not significantly different $(\mathrm{P}=$ 0.05) from each other according to Fisher's protected LSD test.

Table 2: Occurrence of Phytophthora infection of pumpkin leaves and fruits, caused by Phytophthora capsici, following applications of the fungicides in 2015 in Illinois.

\begin{tabular}{|c|c|c|}
\hline \multirow{2}{*}{$\begin{array}{l}\text { Fungicide }{ }^{\mathrm{z}} \text { Treatment and Rate } / \mathrm{Ha} \\
\text { (Application Timing) }\end{array}$} & \multicolumn{2}{|c|}{ Phytophthora Infection } \\
\hline & Infected Vines (\%) ${ }^{\mathrm{x}}$ & Infected Fruit (\%) ${ }^{w}$ \\
\hline Control & $10.00 \mathrm{a}^{\mathrm{v}}$ & $69.17 \mathrm{a}$ \\
\hline $\begin{array}{l}\text { Revus 2.09SC, } 583 \mathrm{~mL}+\text { Kocide-3000 46.1DF, } \\
\text { 1.683kg [1,3,5,7] alt Ranman 400F, } 200 \mathrm{~mL}+ \\
\text { Kocide-3000 46.1DF, 1.683kg }[2,4,6,8]\end{array}$ & $0.00 \mathrm{~b}$ & $26.07 \mathrm{~cd}$ \\
\hline Revus 2.09SC, 583mL [1-8] & $0.00 \mathrm{~b}$ & $25.56 \mathrm{~cd}$ \\
\hline $\begin{array}{c}\text { Revus } 2.09 \mathrm{SC}, 583 \mathrm{~mL}+\text { Kocide-3000 46.1DF, } \\
1.683 \mathrm{~kg}[1-8]\end{array}$ & $5.00 \mathrm{ab}$ & $28.69 \mathrm{bcd}$ \\
\hline $\begin{array}{c}\text { Revus 2.09SC, } 583 \mathrm{~mL}+\text { Activator-90, } 0.25 \% \\
{[1-8]}\end{array}$ & $0.00 \mathrm{~b}$ & $31.25 \mathrm{bcd}$ \\
\hline $\begin{array}{c}\text { Revus } 2.09 \mathrm{SC}, 583 \mathrm{~mL}+\text { Kocide-3000 46.1DF, } \\
1.683 \mathrm{~kg}+\text { Activator-90, } 0.25 \%[1-8]\end{array}$ & $1.25 \mathrm{~b}$ & $17.53 \mathrm{~d}$ \\
\hline Forum 4.16SC, 437mL [1-8] & $2.50 \mathrm{~b}$ & $21.07 d$ \\
\hline Ranman 400F, 200mL [1-8] & $2.50 \mathrm{~b}$ & $41.74 \mathrm{~b}$ \\
\hline $\begin{array}{c}\text { Ranman 400F, 200mL Kocide-3000 46.1DF, } \\
1.683 \mathrm{~kg}+[1-8]\end{array}$ & $3.75 \mathrm{ab}$ & $39.09 \mathrm{bc}$ \\
\hline $\operatorname{LSD}(P=0.05)$ & 6.67 & 15.3 \\
\hline
\end{tabular}

${ }^{2}$ Activator-90 = a nonionic spray adjuvant; Forum 4.16SC = dimethomorph; Kocide-3000 46.1DF = copper hydroxide; Ranman 400F = cyazofamid; and Revus $2.09 \mathrm{SC}=$ mandipropamid.

${ }^{y}$ Application date: $1=20$ August; $2=27$ August; $3=3$ September; $4=10$ September; $5=17$ September; $6=24$ September; $7=31$ September; and $8=7$ October 2015 .

"Vine infection was assessed on 9 October 2015.

wFruit infection was assessed on 30 October 2015 (at harvest).

"Values are averages of four replications. Values within each column with a letter in common are not significantly different $(\mathrm{P}=$ 0.05) from each other according to Fisher's protected LSD test.

Table 3: Occurrence of Phytophthora infection of pumpkin leaves and fruits, caused by Phytophthora capsici, following applications of the fungicides in 2017 in Illinois.

\begin{tabular}{|c|c|c|}
\hline \multirow{2}{*}{ Fungicide $^{\mathrm{z}}$ Treatment and Rate/Ha (Application Timing) } & \multicolumn{2}{|c|}{ Phytophthora Infection } \\
\cline { 2 - 3 } & Infected Vines (\%) $^{\mathbf{y}}$ & Infected Fruit $^{\mathbf{y}}$ (\%) ${ }^{\mathbf{w}}$ \\
\hline Control & $45.00 \mathrm{av}$ & $47.73 \mathrm{a}$ \\
\hline Ranman 400SC, 200mL + Silwet L-77, 146mL [1-8] & $10.00 \mathrm{c}$ & $10.65 \mathrm{~b}$ \\
\hline Ranman 400SC, 200mL [1-8] & 8.75c & $6.71 \mathrm{~b}$ \\
\hline Revus 2.09SC, 583mL [1-8] & $5.00 \mathrm{c}$ & $13.36 \mathrm{~b}$ \\
\hline Revus 2.09SC, 583mL + Activator-90, 0.125\% [1-8] & $6.25 \mathrm{c}$ & $2.06 \mathrm{~b}$ \\
\hline
\end{tabular}

${ }^{2}$ Activator-90 = a nonionic spray adjuvant; Forum 4.16SC = dimethomorph; Kocide-3000 46.1DF = copper hydroxide; Ranman 400F = cyazofamid; Revus 2.09SC = mandipropamid; Silwet L-77 = and a spreader-sticker adjuvant.

yApplication date: $1=27$ June; $2=4$ July; $3=11$ July; $4=18$ July; $5=25$ July; $6=1$ August; $7=8$ August; and $8=15$ August 2017 .

${ }^{x}$ Vine infection was assessed on 12 August 2017.

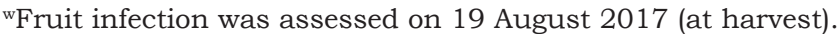

"Values are averages of four replications. Values within each column with a letter in common are not significantly different $(\mathrm{P}=$ 0.05) from each other according to Fisher's protected LSD test. 
Weeds were controlled by hand-weeding. Cucumber beetles (Acalymma vittatum and Diabrotica undecimpunctata) and other insects were managed by applying permryhrin (Pounce 25WP at $740 \mathrm{~mL} / \mathrm{ha}$ ) and acetamiprid (Assail $30 \mathrm{SG}$ at 358g/ha). Spray applications of fungicides were at 7-day intervals, as shown in (Tables 1-3). Fungicides were applied with a backpack sprayer using 469L of water per ha. The plots were irrigated as needed, using a central pivot irrigation line, which delivered $7.6 \mathrm{ml}$ water each time. Incidence of Phytophthora blight in the plots was assessed by examining 20 vines per plot prior to harvest and all of the fruit at harvest.

\section{Results}

\section{In-vitro sensitivity of Phytophthora capsici to fungicides}

Mycelial growth and sporangia production were significantly $(\mathrm{P}=0.05)$ reduced by all three fungicides tested in the laboratory. The $\mathrm{EC}_{50}$ values of the fungicides for mycelial growth ranged from 0.34 to $3.63 \mu \mathrm{g} / \mathrm{mL}$ (average $1.03 \mu \mathrm{g} / \mathrm{mL}$ ); from 0.75 to $4.66 \mu \mathrm{g} / \mathrm{mL}$ (average $2.98 \mu \mathrm{g} / \mathrm{mL}$ ); and from 0.13 to $7.18 \mu \mathrm{g} / \mathrm{mL}$ (average $4.03 \mu \mathrm{g} / \mathrm{mL}$ ) for cyazofamid, dimethomorph, and mandipropamid, respectively. The $\mathrm{EC}_{50}$ value for sporangia production was $10,2.5$, and $0.05 \mu \mathrm{g} / \mathrm{mL}$ for cyazofamid, dimethomorph, and mandipropamid, respectively.

\section{Field trials}

In 2014, vine and fruit infection was first observed in untreated plots on 1 July. Percent vines and fruits infected by $P$. capsici were significantly higher in untreated (control) plots than those in treated plots (Table 1). The lowest incidence of infected vines by $P$. capsici $(6.25 \%)$ was in the plots sprayed with cyazofamid (Ranman 400F) plus Silwet L-77 alternated with mandipropamid (Revus 2.09 SC) plus Activator-90. The lowest incidence of infected fruit by P. capsici (4.45\%) was in the plots sprayed with mandipropamid (Revus 2.09 SC) plus copper hydroxide (Kocide-3000 46.1 DF) plus Activator-90 alternated with cyazofamid (Ranman 400 F) plus Silwet L-77 alternated.

In 2015, vine and fruit infection was first observed in untreated plots on 15 September. Percent vines and fruits infected by $P$. capsici were significantly higher in untreated (control) plots than those of treated plots (Table 2). Incidence of vines infected by P. capsici was $5 \%$ or less in the treated, while incidence of vine infection was $10 \%$ in untreated plots. Incidence of fruit infection in treated plots ranged from 17.53 to $31.25 \%$ compared with untreated plots with $69.17 \%$ fruit infection (Table 2). Incidence of fruit infection was the lowest (17.53\%) in the plots sprayed with Mandipropamid (Revus 2.09 SC) plus copper hydroxide (Kocide-3000 46.1 DF) plus Activator-90.

In 2017, vine and fruit infection was first observed in untreated plots on 15 and 28 July, respectively. Percent vines and fruits infected by $P$. capsici were significantly lower in treated plots that those of untreated (control) plots (Table 3). Incidence of vines infected by $P$ capsici was ranged from 5.00 to $23.75 \%$ in treated plots compare to $45.00 \%$ in untreated (control) plots. Incidence of fruit infection in treated plots ranged from 2.06 to $26.64 \%$ in treated plots compare to $47.73 \%$ in untreated (control) plots (Table 3). The lowest vine infection (5\%) was in the plots sprayed with mandipropamid (Revus 2.09 SC). The lowest fruit infection (2.06\%) was in the plots sprayed with mandipropamid (Revus 2.09 SC) + Activator-90.

\section{Discussion}

Phytophthora blight, caused by P. capsici, is one of the most destructive diseases of cucurbits in the world. Management of this pathogen in cucurbits is a challenging task because no resistant cultivar of cucurbits to P. capsici is available. An important component of strategies for management of $P$. capsici in cucurbits is fungicide application [6]. Developed an effective seed treatment of cucurbits with mefenoxam (Apron XL LS) that prevents plant infection for five weeks from sowing seed in the soil. Over the past 16 years, several effective fungicides were developed for management of $P$. capsici in cucurbits. Among the newly developed fungicides are cyazofamid, dimethomorph, and mandipropamid.

Virulence of $P$. capsici isolates in cucurbits varies among cucurbit producing areas $[3,7]$. Also, P. capsici quickly develop resistance to fungicides [8]. Therefore, testing efficacy of fungicides for management of $P$. capsici in each cucurbit growing areas is essential. Our in-vitro and field tests showed that all three fungicides (cyazofamid, dimethomorph, and mandipropamid) tested are effective against $P$. capsici isolates from Illinois. But applications of these fungicides should be alternated to prevent resistance development in the pathogen. Among the three fungicides tested in fields over the past three years, mandipropamid was the most effective for management of $P$. capsici in pumpkin.

Similar results have been observed in squash and pepper trials in the fields in Illinois (Babadoost, unpublished data). Spray of mandipropamid mixed the Activator-90 and/or a copper compound (e.g., copper hydroxide (Kocide-3000 46.1 DF) is even more effective in reducing the incidence of vine and fruit infection compared to spray of mandipropamid alone. Application of mandipropamid alternated with application of cyazofamid is a reliable fungicide management of $P$. capsici in pumpkins, and likely in other cucurbits crops in Illinois.

\section{References}

1. Babadoost M (2013) Efficacy of selected fungicide for control of Phytophthora blight of processing pumpkin.

2. Erwin DC, Ribeiro OK (1996) Phytophthora diseases worldwide. In: St. Paul (Eds.), American Phytopathological Society, Minnesota, USA.

3. Hausbeck M, Lamour KH (2004) Phytophthora capsici on vegetable crops: Research progress and management challenges. Plant Disease 88(12): 1292-1303.

4. Ristaino JB, Johnston SA (1999) Ecologically based approaches to management of Phytophthora blight on bell pepper. Plant Disease 83(12): 1080-1089.

5. William PH, Zitter TA (1996) Bacterial leaf spot. In: Zitter TA, Hopkins DL, Thomas CE, St. Paul, (Eds.), Compendium of cucurbit diseases. American Phytopathological Society, Minnesota, USA, p: 35.

6. Babadoost M, Islam SZ (2003) Fungicide seed treatment effects on seedling damping-off of pumpkin caused by Phytophthora capsici. Plant Disease 87(1): 63-68. 
7. Islam SZ, Babadoost M, Lambert KN, Ndeme A, Fouly HM (2005) Characterization of Phytophthora capsici isolates from processing pumpkin in Illinois. Plant Dis 89(2): 191-197.

8. Kousik CS, Keinath AP (2008) First report of insensitivity to cyazofamid among isolates of Phytophthora capsici from the southeastern United States. Plant Disease 92(6): 979.

9. Matheron ME, Porchas M (2000) Impact of azoxystrobin, dimethomorph, fluazinam, fosetyl-AI, and metalaxyl on growth, sporulation, and zoospore cyst germination of three Phytophthora spp. Plant Disease 84(4): 454-458.

10. Ristaino JB (2003) Phytophthora blight. In: Pernezny K, Roberts PD, Murphy JF, Goldberg NP, St. Paul, (Eds.) Compendium of pepper diseases. American Phytopathological Society, Minnesota, USA, pp: 17-19.
11. Tian D, Babadoost M (2004) Host range of Phytophthora capsici from pumpkin and pathogenicity of the isolates. Plant Disease 88(5): 485489.

12. Babadoost M, Pavon C (2013) Survival of oospores of Phytophthora capsici in soil. Plant Disease 97(11): 1478-1483.

13. Keinath AP (2007) Sensitivity of population of Phytophthora capsici from South Carolina to mefenoxam, dimethomorph, zoxamide, and cymoxanil. Plant Disease 91(6): 743-748
Creative Commons Attribution 4.0 International License

For possible submissions Click Here

\section{Submit Article}

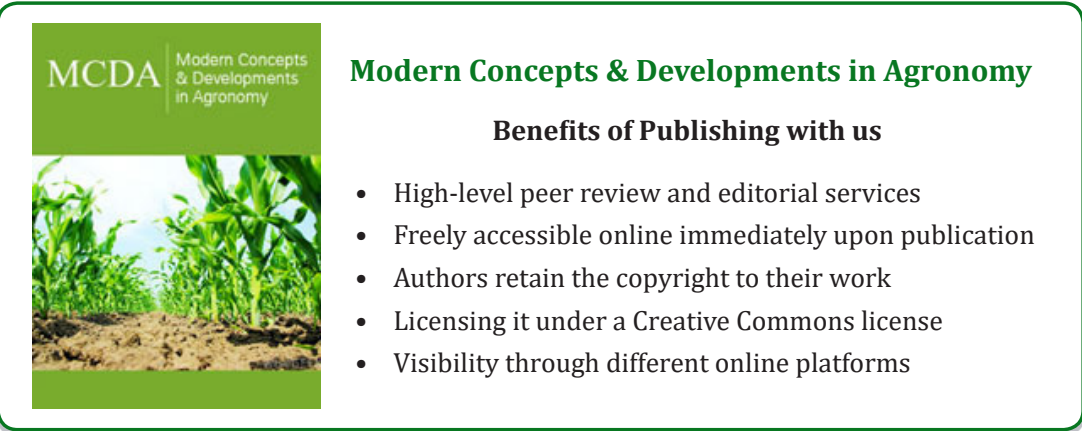

